\title{
Possible futures for Geography and Geographers and Political Geography? A reading from the margins
}

Fiona McConnell

School of Geography and the Environment

Oxford University

'Margins are places from which one may gain a critical vantage point on key political and geographical issues of concern. Discuss.' This is the first essay title that I set students taking my undergraduate course 'Geopolitics in the Margins'. It is also a question that provides a useful provocation for thinking about the present utility and possible futures for Geography and Geographers and Political Geography and, like a well-trained undergraduate, in my comments here I'll seek to unpack this question. Both books take it as their mission to address 'key political and geographical issues of concern' and we could discuss at length the various interpretations of politics in these books, the geographical concept of scale that frames the analysis in Political Geography, and Geography and Geographers foci on canonical concepts of place, space, landscape and territory. However, where I want to focus my attention is on the notion of a 'critical vantage point'. At first glance, both books are written from the perspective of the core. Much can and has been said about the sub-title of Geography and Geographers and a crude interpretation of the Kuhnian approach is one that presents a story of progress, with disciplinary change as a succession of dominant perspectives. Likewise, in many ways Political Geography's world-systems approach gives primacy to the 'rise and fall of great powers (Flint and Taylor 2018, 335) and espouses a ‘one-society assumption’ (ibid 2018, 16), which, whilst assuming universality, nevertheless has been developed from the Western core. Yet, margins, in various guises, are frequently mentioned in both texts and in many ways underpin the political agenda behind these volumes. The later editions of Geography and Geographers acknowledge the limitations of the paradigm model and pay ever more attention to silences and alternative voices in the history of geography, with expanded chapters on radical, postcolonial and feminist geographies, and a final chapter that strikes a refreshingly reflexive tone about the partial nature of knowledge production.

Turning to Political Geography, whilst there is surprisingly no entry in the index for margins or marginalisation, the dynamics core-periphery inequalities of the capitalist world-economy is a central theme running through the volume. In my course the students and I work through a range of approaches to understanding the concepts of margins and marginality. This includes early sociological work on the 'marginal man' by Robert Park (1928), as 
well as charting how the concept of the margins has been interrogated by geographers. Whilst the course focuses on social constructionist understandings of marginality as relational and postcolonial and feminist critiques of the politics of knowledge production, we also spend time engaging with structuralist approaches. We read Political Geography alongside reports of the much overlooked IGU Commission 'Marginalization, Globalization and Regional and Local Responses' whose work is perhaps the most direct engagement by geographers with the idea of structural marginality. These approaches to the margins have in many ways shaped our discipline, bringing to the fore a scalar and networked mode of analysis. Yet they also present a rather static view of the margins, seeing centres and margins as spatial categories fixed by previous rounds of capital accumulation, and of there being an assumed hierarchical relationship between centrality and marginality.

What then of the possible futures for these books and how could they bring the margins - broadly defined centre-stage? One option is the continuation of the current trajectory, with $8^{\text {th }}$ editions of each text being expanded to incorporate new developments in the discipline and provide a response to the rapidly shifting geopolitical realities. Whilst this would continue what is an incredibly rich and enlightening series of editions, I want to ponder what more radical futures might look like for these books. Turning first to Political Geography, although the later editions have a broader remit, for me the book continues to tell too neat a story. In asking whether some of the 'hard edges' of world-systems approach could be softened and the silences, gaps and fuzzy borders of the capitalist world-economy be brought to the fore I wonder whether a solution might actually be hidden within the $7^{\text {th }}$ edition. Somewhat surprisingly given the focus on core-periphery power relations there is only one entry for post-colonialism in the book's index. This is for a text box on 'the post-colonial voice' which, whilst acknowledging the theoretical tensions between post-colonial studies and the world-systems approach, argues that these are creative tensions and that the two approaches are 'kindred spirits' in terms of seeking to identify and address structural inequalities (Flint and Taylor 2018, 121). What if this creative tension was put at the core of the book and the claim that 'the nature of political change emanates from the periphery of the capitalist world economy rather than from the core' (ibid) is fully interrogated. In other words, could the volume be reworked so that it is written from the vantage point of the margins?

In terms of Geography and Geographers my suggestion is also to make the book a less comfortable read, but here I posit a different future format rather than changes to content. Returning to the notion of a critical vantage point, a recurrent lens in how the book is both envisaged by the authors and perceived by reviewers is that of 
cartography. There is certainly something reassuring about a 'road map' to the modern history of human geography, however what is lost are the multitude of disciplinary meanderings. To capture these I wonder whether there might be utility in an interactive digital platform accompanying the book, with perhaps mindmaps of the discipline drawn by geography students, teachers and academics, family trees charting connections between ideas and people, or trails of what Anderson and Larson term 'marginalia, or the knowledge of excess,' 'leftover notes, discarded drafts, awkward anecdotes, and other detritus that accumulate around and in opposition to any given research project' $(2013,739)$. Somewhat akin to the 'choose your own adventure' books that were popular when both volumes were first published, I wonder whether such a format might provide a vantage point from which the medley of margins that is contemporary human geography might more clearly come into view.

\section{References}

Anderson, C. \& Larson, S. (2013). 'Marginalia, or the Knowledge of Excess'. Social and Cultural Geography, 14(7), 739-43.

Flint, C. \& Taylor, P. J. (2018). Political Geography: World-economy, Nation-state and Locality. Abingdon: Routledge.

Johnston, R. \& Sidaway, J. D. (2016). Geography and Geographers: Anglo-American Geography since 1945. Seventh Edition. Abingdon: Routledge.

Park, R. E. (1928). Human Migration and the Marginal Man. American Journal of Sociology, 33: 881-893. 